\title{
Inactivation of Pseudomonas aeruginosa by zinc oxide nanoparticles in aqueous solution
}

\author{
A Maleki $^{1 *}$, M Ahmadi Jebeli ${ }^{1}$, E Kalantar ${ }^{1,2}$, H Daraei $^{1}$, B Davari $^{1,3}$, M Safari ${ }^{1}$ \\ From 3rd International Conference on Prevention and Infection Control (ICPIC 2015) \\ Geneva, Switzerland. 16-19 June 2015
}

\section{Introduction}

Since $\mathrm{ZnO}$ nanoparticles (ZnO-NPs) exhibit strong antibacterial activities on a broad spectrum of bacteria the aim of this study was to evaluate the antimicrobial activity of Zno-NPs against Pseudomonas aeruginosa as a model for gram-negative bacteria.

\section{Methods}

The average size of Zno-NPs was $20 \mathrm{~nm}$, as determined through scanning electron microscopy. Muller Hinton broth was used as a growing medium for Pseudomonas aeruginosa. Photocatalytic experiment was carried out in a laboratory-scale batch reactor with low pressure ultraviolet irradiation $(380 \mathrm{~nm})$. Different experimental parameters such as amount of Zno-NPs, contact time, inorganic and organic substances and $\mathrm{pH}$ on photocatalytic inactivation of Pseudomonas aeruginosa cells have been studied. An initial Pseudomonas aeruginosa concentration of $10^{8} \mathrm{CFU} / \mathrm{mL}$ was used for all experiments.

\section{Results}

Result showed that, almost all the initial Pseudomonas aeruginosa cell $\left(10^{8} \mathrm{CFU} / \mathrm{ml}\right)$ was inactivated in $60 \mathrm{~min}$ in the presence of $2 \mathrm{~g} / \mathrm{l} \mathrm{ZnO}$-NPs. Photocatalytic inactivation of bacteria was found to follow first order kinetics. The initial $\mathrm{pH}$ of the water did not play an important role on the inactivation rate within a range of $6-8 \mathrm{pH}$ units. The amount of photocatalyst also plays an important role in photocatalytic inactivation rate. As the result showed increasing the photocatalyst amount provided more rapid inactivation.

\section{Conclusion}

Addition of some inorganic ions to the suspension affects the sensitivity of Pseudomonas aeruginosa and caused to retard the inactivation rates. Since the sensitivity of Pseudomonas aeruginosa to photocatalytic treatment was fairly good, it is therefore, recommended to use this nano-particle for water treatment.

\section{Disclosure of interest}

None declared.

\section{Authors' details}

'Kurdistan Environmental Health Research Center, Kurdistan University of Medical Sciences, Sanandaj, Iran, Islamic Republic Of. ${ }^{2}$ Department of Microbiology and Immunology, School of Medicine, Alborz University of Medical Sciences, Karaj, Iran, Islamic Republic Of. ${ }^{3}$ Department of Medical Entomology, School of Medicine, Hamadan University of Medical Sciences, Hamadan, Iran, Islamic Republic Of.

Published: 16 June 2015

doi:10.1186/2047-2994-4-S1-16

Cite this article as: Maleki et al:: Inactivation of Pseudomonas aeruginosa by zinc oxide nanoparticles in aqueous solution. Antimicrobial Resistance and Infection Control 2015 4(Suppl 1):16.

Submit your next manuscript to BioMed Central and take full advantage of:

- Convenient online submission

- Thorough peer review

- No space constraints or color figure charges

- Immediate publication on acceptance

- Inclusion in PubMed, CAS, Scopus and Google Scholar

- Research which is freely available for redistribution

Submit your manuscript at www.biomedcentral.com/submit
() Biomed Central

Kurdistan Environmental Health Research Center, Kurdistan University of Medical Sciences, Sanandaj, Iran, Islamic Republic Of

Full list of author information is available at the end of the article 